\title{
Verbalmodus og sætningsmodus
}

\author{
Kasper Boye \& Peter Harder
}

\begin{abstract}
This article takes its point of departure in the need for a clarification of the relation between sentence mood ("sentence type") and verbal mood. The centrepiece of the theory defended in the article is that while sentence types like declarative, interrogative and imperative encode a contrast between sentence-level, conventional illocutionary types, verbal mood encodes the referential status of the described situation encoded by the clause. A basic contrast, we argue, involves the contrast between propositions (as encoded by the indicative mood), which are understood as referring to aspects of the discourse world, and states-of-affairs, which have no such referential relation.
\end{abstract}

Nøgleord: sagforhold, proposition, referentialitet, sætningsillokution, paradigmatisk kontrast

\section{Introduktion: Verbalmodus og sætningsmodus}

Modus er traditionelt (jf. de latinske grammatikker) et overbegreb for modsætningen mellem indikativ, konjunktiv og imperativ, opfattet som former af verbet. Sondringen mellem forskellige sætningstyper eller sætningsillokutioner er kommet på dagsordenen senere. Den bruges primært om deklarativ, interrogativ og imperativ (major sentence types), med visse sekundære alternativer (fx eksklamativ, sætninger indledt af gid, osv.).

De to kategorier hører hjemme forskellige steder i den lagdelte indholdssyntaks: Sætningsillokution ligger øverst i hierarkiet og tager verbalmodus i sit virkefelt (skopus). Dette er tydeligst ved valget mellem sætningsillokutionerne interrogativ og deklarativ, der begge har indikativ verbalmodus i deres virkefelt, jf. modsætningen mellem den deklarative sætning det regner og den interrogative regner det? I begge tilfælde er der tale om det samme indikative sætningsindhold, der henholdsvis gøres gældende som sandt (deklarativ) og fremsættes med henblik på bekræftelse eller afkræftelse (interrogativ). 
I dette tilfælde er sondringen mellem de to niveauer klar. Der er imidlertid en sammenhæng mellem de to niveauer, som ikke altid er lige klar. Et eksempel er at "imperativ" typisk figurerer på begge niveauer: Det er dels en sætningstype (på dansk kendetegnet ved at der typisk ikke indgår et grammatisk subjekt) og dels en verbalform (kendetegnet ved at være lig med stammen, i de fleste tilfælde lig med infinitivsformen minus -e): spis! Præcis hvad egenskaberne er ved den verbalmodus imperativen som sætningstype tager i sit skopus, tematiseres sjældent. Der er derfor behov for at forholdet mellem de to sæt kategorier bliver afklaret. Denne artikels centrale tese er at verbalmodus kan forstås som omhandlende referentialitet, dvs. at verbalmodus indkoder sætningsindholdets relation til verden. Vi vil desuden argumentere for på hvilken måde en sådan teori må involvere både semantisk substans og strukturelle relationer.

\section{Sondringen mellem sagforhold og proposition}

Udgangspunktet for diskussionen er forholdene i dansk. Vi vil argumentere for at man i dansk kan redegøre for forholdene på verbalmodus-plan ved at skelne mellem følgende to muligheder: 1) Indikativ, som illustreret med eksemplet det regner/regner det, udtrykker en proposition. 2) Imperativ, som i regn, udtrykker et sagforhold (Boye 2013).

De to begreber, proposition og sagforhold, er kendt fra litteraturen. Sondringen mellem dem er tematiseret i Funktionel Grammatik (Dik \& Hengeveld 1991), og i kognitiv grammatik dukker den op som en forskel mellem grundede (grounded) og ikke-grundede processer (jf. Langacker 1991: 551). De to begreber tilkendes imidlertid ikke generelt den status som vi gerne vil argumentere for her. Grundlaget for analysen i denne artikel er (som beskrevet i Boye 2010; 2012) en sondring mellem referentiel og ikke-referentiel semantisk instruks. Indikativiske sætninger, der indkoder propositioner, er konventionelt forsynet med en instruks om at de skal læses som referentielle. Dvs. at det prædicerede indhold der er fælles for de to sætninger det regner/regner det, skal opfattes som en beskrivelse af en situation i verden. Det er denne referentielle relation der gør at de har en sandhedsværdi. I modsætning hertil er imperativiske sætninger, der koder sagforhold, ikke forsynet med en instruks om at de skal læses som referentielle. Det prædicerede indhold i gå du bare! skal ikke opfattes som en beskrivelse af en situation i verden, men vækker blot forestillingen om en sådan situation - som lytteren så evt. kan bringe i stand $\mathrm{i}$ verden.

Denne analyse er grundlæggende i samklang - men ikke identisk - med 
de to andre opfattelser der er refereret ovenfor. Hengeveld opfatter sagforhold og proposition som to ontologisk forskellige typer af referenter (jf. også Lyons om second-order- over for third-order-entitet). Langacker beskriver forholdet som en forskel mellem to konceptualiseringer og inddrager ikke instruks om reference i beskrivelsen.

Den fælles forståelse omfatter at sagforhold kan siges at forekomme eller eksistere og kan udtrykkes i prædikationer som at spise hvidlog. Propositioner kan siges at være enten sande eller falske, og de kan som illustreret bl.a. udtrykkes i indikativiske sætninger (uanset om de er deklarative eller interrogative). Både Trump vandt presidentvalget 2016 og vandt Trump presidentvalget i 2016? handler om det prædicerede indholds sandhedsværdi; om begge kunne man spørge "sandt eller falsk?" - og svaret ville være "sandt".

Teorien indebærer også at kun propositioner kan evalueres epistemisk. Dette har diagnostisk værdi i visse tilfælde:

(1) Jan så nok Ib (*måske) spille fodbold.

(2) Jan indså nok at Ib (måske) spillede fodbold.

(1) tillader ikke epistemisk evaluering i komplementsætningen (og det betyder at der er tale om et sagforhold). (2) tillader derimod epistemisk evaluering (og indholdet $\mathrm{i}$ komplementsætningen må derfor opfattes som en proposition). Sondringen kan også differentiere mellem modalverbers betydning, jf. (3).

Jens kan være i huset.

En dynamisk læsning af kan ('evne i det grammatiske subjekt', i eksemplet måske at Jens ikke er allergiker) hører sammen med en sagforholdslæsning af infinitiven. En epistemisk læsning af kan ('det kan tænkes at') hører sammen med en propositionel læsning af infinitiven: 'det kan være sandt at Jens er i huset'.

Denne tolkning lader sig også anvende på verbalmodus-delen af imperativer. Imperativs betydning gengives altid som sætningsillokutionær (direktiv). Som nævnt efterlader dette spørgsmålet om betydningen på verbalmodusniveauet ubesvaret. Sondringen mellem proposition og sagforhold kan levere et bud: Hvor indikativ verbalmodus indkoder en proposition, indkoder imperativ som verbalmodus et sagforhold.

Det svarer til det forhold at det beskrivende indhold af indikativiske sætninger kan være sandt eller falsk, mens det beskrivende indhold af imperativiske sætninger kan forekomme eller indtræffe. Det prædicerede indhold af imperativsætningen gå hjem! skal ikke evalueres som sandt eller falsk i 
forhold til en situation som der refereres til. Indholdet af et påbud er netop at et sagforhold skal bringes til at indtræffe ved adressatens foranstaltning.

Modsætningen mellem de to sætningsmodale betydninger er således privativ i pragsk forstand. Indikativ har et betydningselement som alternativet mangler: den referentielle instruks om at sammenholde det prædicerede indhold med den situation der refereres til (eller sagt på en anden måde: at hægte det prædicerede indhold på den situation der refereres til). Dette privative forhold rummes ikke i teorier der taler om forskelle mellem to konceptualiseringer (Achard 2002), om forskelle i direction-of-fit (Searle 1983) eller om forskellige slags referenter for de to udsagnstyper (fx. Hengeveld 1990). Den privative modsætning afspejles ikonisk i det forhold at indikativer i forskellige sprog typisk er morfologisk mere komplekse end imperativer. I dansk viser det sig ved at imperativer ikke har tempusbøjning, hvilket afspejler det forhold at tempus foruden den tidsdeiktiske betydning netop markerer at indholdet har status af proposition: Det er gyldighedstidspunktet der indekseres, ikke handlingstidspunktet (jf. Harder 1996: 330).

\section{Konjunktiv (med udblik til engelsk, tysk og fransk)}

I den grammatiske litteratur er den klassiske modsætning i verbalmodus modsætningen mellem indikativ og konjunktiv. Vi kan begynde med at observere at konjunktiv har samme problem som imperativ når det gælder klar adskillelse mellem hvad der indkodes på sætningsillokution-niveauet og verbalmodus-niveauet.

Traditionelle grammatiske fremstillinger har typisk oversigter over konjunktivens forskellige anvendelser, herunder ofte anvendelser i hovedsætninger og i ledsætninger. Hovedsætningsanvendelserne har typisk status af sætningsmodi (sætningstyper), og det har også de residuale forekomsttyper man kan pege på i dansk. Den type sætningsillokution man kan kalde "optativ" - med en traditionel dansk betegnelse "ønskeform" - er bevaret i et antal formularer, hvoraf eder og forbandelser (Fanden hente ham!) måske er de mest levende. Men med lidt god vilje kan man opstille en treleddet modsætning her, som kan genfindes på beslægtede sprog.

(4) Gud forbyde det. (Konjunktiv)

(5) Gud forbyder det. (Indikativ)

(6) Gud, forbyd det! (Imperativ) 
Beskrevet i overensstemmelse med den teori vi har fremlagt ovenfor, er det sådan at mht. indkodet indhold på verbalmodus-niveauet er konjunktiv ikke forskellig fra imperativ i sådanne eksempler. Det drejer sig i begge tilfælde om et sagforhold der præsenteres som noget man ønsker skal bringes til at indtræffe - der er ingen reference til en bestemt situation og ingen sandhedsværdi. Modsætningen mellem konjunktiv og indikativ er derfor, ligesom beskrevet ved imperativ ovenfor, et privativt forhold. Det betyder at konjunktiv i denne henseende er semantisk umarkeret i forhold til indikativ - sml. Heltoft (2002: 93) om indikativens realitetstilknytning som det markerede i forhold til konjunktivens ikke-tilknytning. (Selvom konjunktiv således er umarkeret i denne forstand, kan det dog godt i en anden forstand være markeret som det "afvigende" valg, jf. også Heltoft herom). Forskellen mellem imperativ og konjunktiv ligger alene på det sætningsillokutive plan: 'påbud om handling' (potentielt "ansigtstruende") over for 'fromt ønske'.

På engelsk kan man i visse tilfælde opstille et (i traditionel beskrivelse) konjunktivisk verbalmodus-indhold i ledsætninger. I sådanne tilfælde optræder med andre ord en verbalmodus uden at være direkte i skopus af et sætningsillokutivt indhold à la "ønskeform”. Det gælder bl.a. den såkaldte "mandative konjunktiv":

(7) It is important that she get all the necessary assistance.

Denne konstruktionstype kan uden vanskeligheder rummes i den foreslåede teori: Her har undersætningen she get all the necessary assistance "sagforholdsmodus", men ingen selvstændig sætningsillokution.

Som påpeget af Palmer (1979) kan dette beskrives uden at man behøver at postulere en konjunktiv på engelsk, hvilket er ønskeligt bl.a. fordi der ikke på engelsk er distinktive verbalformer der markerer konjunktiv (konjunktiv er lig med verbernes grundform, ligesom imperativ og infinitiv). Det har været foreslået at formen skulle opfattes som en imperativ i ledsætningsposition, men som påpeget af Huddleston \& Pullum et al (2002: 943-44) er den mandative konstruktion bredere end imperativen. (7) er taget fra deres fremstilling som eksempel på en form der ikke har nogen modsvarighed i en imperativsætning.

Man kan derfor - ligesom på dansk - nøjes med at opstille en umarkeret sætningsmodus (den privative modsætning til indikativ). Forskellen i forhold til dansk er således kun den at man på engelsk har en konstruktion hvor der ved et antal verber er en paradigmatisk modsætning mellem indikativ 
og "umarkeret" verbalmodus, som eksemplificeret her (cf. Huddleston \& Pullum et al. 2002:996):

(8) I suggest she doesn't like us very much. (Proposition der er sand eller falsk.)

(9) I suggest you go and see a doctor. (Sagforhold der skal iværksættes.)

Den omstændighed at indholdet af den "mandative" ledsætning mht. sætningsillokution somme tider svarer mest til imperativ, som i (9): 'go and see a doctor!', sommetider mest til ønskeform, som i (7): 'may she get all the necessary assistance!', er naturlig hvis man antager at det konventionelle indhold på verbalmodusplan er sagforholdet, mens det beror på konteksten om man kan indfortolke den ene eller den anden sætningsillokutive handlingstype. Vi mener derfor at den løsning vi foreslår, på en og samme tid gør rede for de ligheder der er mellem den mandative konstruktion på den ene side og imperativ og konjunktiv på den anden, og tillige de grunde der er til ikke at opfatte den som manifesterende samme kategori som hverken imperativ eller (hovedsætnings-)konjunktiv.

Vi har her argumenteret for at man kan gøre tilfredsstillende rede for verbalmodus-semantikken i engelsk og dansk alene ved en modsætning mellem proposition og sagforhold. Vi vil nu diskutere forholdene i fransk, hvor der foreligger en morfologisk veldefineret konjunktiv.

Også i diskussionen af fransk genfinder man den lidt uklare sondring mellem sætningsillokution og verbalmodus. Det gælder således i den såkaldte assertionsteori, som placerer konjunktiv i modsætning til "asserteret indhold" (jf. Terrell \& Hooper 1974). Som påpeget af Lindschouw (2011) dækker denne teori ikke forholdene i nutidigt fransk; men dette udelukker ikke at den peger på en relevant indsigt, som vi blot mener må omformuleres så arbejdsdelingen mellem sætningsillokutiv betydning og verbalmodusbetydning kommer klarere frem.

Generelt gælder det at konjunktiv i moderne fransk kun i begrænset omfang optræder som distinktiv markør af semantiske forskelle, både når det gælder sætningsillokution og når det gælder forskelle på verbalmodusplan. Dette kan fortolkes på den måde at morfologiske konjunktivformer ofte må opfattes som en del af specifikke konstruktionelle profiler, dvs. at der findes et inventar af komplekse udtryk der som et træk har anvendelsen af morfologisk konjunktiv. Dette udelukker ikke at disse konstruktioner kan have semantiske fællestræk, som går igen i de frie, produktive forekomster. 
Det ligger uden for formålet med denne artikel at gå ind i en nærmere diskussion heraf. Vores pointe er at sondringen mellem proposition og sagforhold også kan kaste lys over de måske mest typiske af de produktive forekomster i fransk. Mønsteret fremgår fx af følgende eksempler (med tak til Jan Lindschouw):

(10) Indikativ

Le président a dit que le ministre de l'intérieur est là. (Prosposition med sandhedsværdi.)

'Præsidenten har sagt at indenrigsministeren er/vil være til stede'.

(12) Konjunktiv

Le président a dit que le ministre de l'intérieur soit là. (Sagforhold der skal iværksættes.)

'Præsidenten har sagt/dekreteret at indenrigsministeren skal være til stede'.

(13) Indikativ

Je cherche quelqu'un qui peut m'aider.

(Proposition: om den person jeg søger, gælder det, at vedkommende kan hjælpe mig.)

'Jeg søger en person der kan hjælpe mig'.

(14) Konjunktiv

Je cherche quelqu'un qui puisse m'aider.

(Sagforhold der skal iværksættes: Der skal findes en egnet person.) 'Jeg søger en person der kan hjælpe mig'.

Eksemplerne illustrerer at $\mathrm{i}$ indikativ omtales situationer og referenter som noget der refererer til forhold i virkeligheden, men i konjunktiv stipuleres en beskrivelse som skal instantieres ("indtræffe"). Denne analyse er forenelig med at opfatte konjunktiv som udtrykkende et sagforhold, mens indikativ udtrykker en proposition.

En sidegevinst ved denne beskrivelse er at der opnås en parallel analyse mellem selvstændige ytringer og gengivne ytringer: (10), der gengiver en assertion, udtrykker et propositionelt indhold, ligesom den gengivne assertion ('ministeren er til stede') gør; (11), der gengiver et direktiv, udtrykker et sagforhold, ligesom det gengivne direktiv gør (jf. også Sørensen \& Boye 2017). Yderligere en fordel er at analysen giver en direkte parallel med 
+/- referentiel tolkning af NP'er og +/- referentiel tolkning af prædikation (svarende til hhv. proposition og sagforhold): I indikativ-eksemplerne er ubestemte NP'er typisk referentielle (=specifikke), ligesom propositionerne i dem er det; i konjunktiveksemplerne er ubestemte NP'er ikke-referentielle, ligesom sagforhold heller ikke er det.

Analysen er hidtil baseret på det rene alternativ mellem propositioner (refererende) og sagforhold (ikke-refererende). Den mere generelle teori om at verbalmodus kan forestås som noget der vedrører referentialitet af det prædicerede indhold, er imidlertid ikke udtømt med denne basale modsætning. I andre sprog er der eksempler på at "konjunktiv" på verbalmodusplan indkoder et tredje alternativ, der også kan forstås inden for denne ramme. Det gælder fx den såkaldte "konjunktiv II" på tysk.

Vi låner eksemplet fra Jakobsen \& Heltoft (2012: 98).

Kontekst:

(15) Ich konnte schiessen, das hatten sie mir beigebracht.

'Jeg kunne skyde - det havde de lært mig'.

Fortsættelse (A), indikativ:

Und ich hatte geschossen - auf die Feinde meines Führers

und meines Vaterlandes.

'Og jeg havde skudt - på min førers og mit fædrelands fjender'.

Fortsættelse (B), konjunktiv:

Und ich hätte geschossen - auf die Feinde meines Führers und meines Vaterlandes.

'Og jeg ville have skudt - på min førers og mit fædrelands fjender'.

Vigtigt er her at sætningsillokutionen både i indikativ-tilfældet og også i konjunktiv-tilfældet er 'assertion'. Derfor må indholdet i begge tilfælde have status af en proposition, ikke et sagforhold. På verbalmodusplan indkodes her en forskel der har at gøre med hvilken type situation indholdet gælder. Indikativ markerer at der refereres til den virkelige verden, mens konjunktiv i dette tilfælde markerer at der henvises til en hypotetisk situation. Også dette har med referenceforhold at gøre og er klart adskilt fra spørgsmålet om sætningstype, altså konventionel talehandlingstype. 


\section{Paradigmer, semantisk substans og forholdet mel- lem tvarsproglige og sarsproglige kategorier}

Som det også er fremgået af ovenstående, udtrykker den traditionelle term "konjunktiv" ikke en semantisk konstant. Termen kan derfor ikke placeres entydigt på et semantisk kort og derfor heller ikke bruges som typologisk parameter (comparative concept, jf. Haspelmath 2010), hvis vi dermed kun tænker på et konkret kodet indhold. Semantisk set er konjunktiv et særsprogligt fænomen, med betydninger der ikke er organiseret omkring en tværsproglig semantisk prototype.

Analysen viser imidlertid også at man kan skabe et grundlag for tværsproglig beskrivelse, hvis man til den rent semantiske beskrivelse - i bedste overensstemmelse med traditionerne fra europæisk strukturalisme - inkluderer en paradigmatisk analyse, samtidig med at man tager udgangspunkt i en analyse der tager højde for hvor i indholdssyntaksen de relevante betydningsstørrelser og -modsætninger hører hjemme. Man må i hvert enkelt tilfælde gennemføre en semantisk analyse à la den vi har skitseret.

Hvis disse betragtninger medtages i analysen, kan man opstille to adskilte, men indbyrdes forbundne semantiske paradigmer, hjemmehørende på hver sit veldefinerede sted i den lagdelte indholdssyntaks, som et godt grundlag for at skabe klarhed i forholdet mellem sætningsmodus og verbalmodus.

Sætningsmodus hører hjemme i toppen af den lagdelte syntaks og tager resten af sætningsindholdet $\mathrm{i}$ sit skopus, idet dette rekrutteres som indhold $\mathrm{i}$ en bestemt konventionel talehandlingstype (deklarativ, interrogativ, direktiv m.v.). Verbalmodus tager det prædicerede indhold i sit skopus og placerer det mht. reference, dvs status i forhold til den omtalte virkelighed.

Sammenhængen mellem de to paradigmer ligger bl.a. i at visse talehandlingstyper kræver en proposition (man kan kun assertere noget der har referentiel status), mens andre kræver et sagforhold (man kan kun ønske noget iværksat, der har status af et sagforhold). Den delvise uafhængighed består bl.a. i at såvel propositioner som sagforhold (på verbalmodus-plan) kan forbindes med forskellige sætningsmodi: deklarativ over for interrogativ for propositionernes vedkommede, imperativ over for ønskemåde for sagforholds vedkommende. Kombinationen af uafhængighed og samhørighed viser sig også ved at når verbalmodus optræder i ledsætninger, altså uden at være direkte i skopus af en sætningsmodus, kan man stadig påvise en semantisk affinitet med de relevante verbalmodi og de sætningsmodi de hører sammen med.

Mht. verbalmodus har vi argumenteret for at modsætningen mellem proposition (referentiel fortolkning i forhold til den omtalte virkelighed) og 
sagforhold (ikke-referentiel fortolkning) spiller en vigtig rolle i sprog som dansk, engelsk og fransk. I sprog som dansk og engelsk er en analyse mulig uden at antage eksistensen af en særlig konjunktiv-modus.

Som diskuteret med den tyske konjunktiv II som eksempel kan der tænkes andre referentielle statusser end disse to - og begrebets anvendelighed er derfor ikke begrænset til denne basale modsætning.

Vi hævder imidlertid ikke at denne analyse kan bringes til at dække alle modsætninger der traditionelt er anbragt under overskriften "konjunktiv". Der vil også være brug for andre former for oprydning for at dække forholdet mellem betydningszoner og morfologiske valg (herunder tilfælde hvor morfologien er uden systematisk semantisk korrelat, og kun en analyse i form af idiosynkratiske træk ved komplekse konstruktioner er mulig).

Nødvendigheden af at have både en semantisk, en paradigmatisk og en morfologisk komponent kan beskrives som følger.

Udgangspunktet for hele analysen er en præcis semantisk analyse af hvad modusformer konventionelt udtrykker. Når denne analyse er gennemført, må man imidlertid supplere med en analyse af hvor i det semantiske hierarki disse betydninger hører hjemme - kun derved kan man få et klart billede af arbejdsdelingen mellem betydninger på sætningsmodus-niveau og verbalmodus-niveau. Forskellen mellem sagforhold og proposition kan have forskellig status i beskrivelsen afhængigt heraf. Fx kan sagforhold optræde i konstruktioner à la at vare eller ikke vare, hvor de ikke er i skopus hverken af en oversætning eller en sætningsillokution - og i sådanne tilfælde er der ingen motivation for at opfatte sagforhold som udgørende en modus. Hertil kræves en forståelse af de forskellige typer status nulformer kan have, jf. også Nielsen (2016). Det er kun når en ikke-referentiel prædikation står som paradigmatisk alternativ til en referentiel prædikation, at den kan få status af verbalmodus.

For at få en retvisende tværsproglig analysemodel er en morfologisk dimension desuden nødvendig. Den engelske såkaldt mandative konjunktiv indgår $\mathrm{i}$ et paradigmatisk valg mellem verbalformer med tilsvarende semantisk forskel (som ikke har modsvarighed i dansk). Derfor udgør dette en modusforskel på engelsk - men der kræves ikke en analyse der opererer med en særlig konjunktivisk modus, for at opfange dette træk i engelsk: Man behøver kun den semantiske modsætning mellem to modusindhold, der genfindes andre steder i systemet: sagforholds- og propositionel modus.

Et tværsprogligt "komparativt begreb" om konjunktiv kan opstilles ved at man stipulerer eksistensen af et sæt af morfologisk distinktive former som indkoder en modusforskel i situationer hvor disse ellers ikke ville have 
konventionel status. Ifølge den opstillede teori vil det være konjunktivens opgave som morfologisk kodet modus at signalere forskelle i referentiel status - og disse forskellige referentielle statusser kan så atter indgå i hele sætningsindhold, enten ved direkte at indgå i skopus for sætningsillokutioner (i helsætninger) eller ved at optræde for sig selv i ledsætninger.

\section{Konklusioner}

Verbalmodus og sætningsillokution udgør to semantiske paradigmer, men der er tætte semantisk motiverede bånd mellem valgene i de to paradigmer. Arbejdsdelingen og relationen kan beskrives ved at opfatte referentiel status som central betydningszone for verbalmodus, således at referentialitet (indikativ modus) er nødvendig for fx en deklarativ sætningsmodus, mens ikkereferentialitet (sagforholds-modus) er nødvendig for direktive sætningsmodi.

Det semantiske valg mellem sagforhold og proposition genfindes andre steder end de beskrevne, men har kun status af modusvalg under de bestemte paradigmatiske betingelser der er beskrevet. Derfor kan en modus-teori kun tænkes som en kombination af en teori om semantisk substans og en teori om paradigmatisk organisering af indholdssyntaksen.

Med den kombination af en semantisk, en paradigmatisk og en morfologisk dimension i analysen som her er foreslået, kan man opstille et sammenligningsgrundlag der gør det muligt at diskutere konjunktiv i tværsproglig sammenhæng.

\section{Om forfatterne}

Kasper Boye, ph.d., Institut for nordiske sprog og sprogvidenskab, Københavns Universitet.

Peter Harder, dr.phil., Institut for Engelsk, Germansk og Romansk, Københavns Universitet.

\section{Litteratur}

Achard, M. (2002): The meaning and distribution of French mood inflections. I: Grounding: The epistemic footing of deixis and reference. Brisard, F. (red.). Berlin, New York: Mouton de Gruyter, 197-249.

Boye, K. (2010): Reference and clausal perception-verb complements. Linguistics 48, 391-430. 
Boye, K. (2012): Epistemic meaning: A crosslinguistic and functional-cognitive study. Berlin: Mouton de Gruyter.

Boye, K. (2013): Sagforhold, propositioner og den danske indikativ. I: $\mathcal{N y}$ forskning i grammatik 20. Falster Jakobsen, L., Kragh, K.J., Jensen, E.S. \& Strudsholm, E. (red.). Odense: Institut for Sprog og Kommunikation, Syddansk Universitet, 31-52.

Dik, S.C. \& Hengeveld, K. (1991): The hierarchical structure of the clause and the typology of perception-verb complements. Linguistics 29, 231-259.

Harder, P. (1996): Functional semantics. Berlin: Mouton de Gruyter.

Haspelmath, M. (2010): Comparative concepts and descriptive categories in cross-linguistic studies. Language 86 (3), 663-687.

Heltoft, L. (2002): Modality and subjectivity. In: Modality. Studies in form and function. Klinge, A. \& Müller, H.H. (red.). London, Oakville: Equinox, 81-101.

Hengeveld, K. (1990): The hierarchical structure of utterances. I: Layers and levels of representation in language theory: A functional view. Nuyts, J., Bolkestein, A.M. \& Vet, C. (red.). Amsterdam, Philadelphia: Benjamins, 1-24. Huddleston, R. \& Pullum, G.K. (2002): The Cambridge Grammar of the English Language. Cambridge: Cambridge University Press.

Jakobsen, L.F. \& Heltoft, L. (2012): Paradigm formation: Changes of function and structure in German and Danish mood systems. Acta Linguistica Hafniensia 44 (1), 77-107.

Langacker, R.W. (1991): Foundations of cognitive grammar, Vol. 2: Descriptive application. Stanford: Stanford University Press.

Lindschouw, J. (2011): Etude des modes dans le système concessif en français $d u$ $16^{e}$ au $20^{e}$ siècle et en espagnol moderne, evolution, assertion et grammaticalisation. København: Museum Tusculanum.

Lyons, J. (1977): Semantics. Cambridge: Cambridge University Press.

Nielsen, P.J. (2016): Functional structure in morphology and the case of nonfinite verbs. Theoretical issues and the description of the Danish verb system. Leiden: Brill. Palmer, F.R. (1979): Modality and the English modals. London: Longman.

Searle, J.R. (1983): Intentionality: An essay in the philosophy of mind. Cambridge: Cambridge University Press.

Sørensen, M.-L.L. \& Boye, K. (2017): Lagdelt indholdsstruktur i selvstændige ytringer og direkte og indirekte ytringsgengivelse. I: Ny forskning i grammatik 24. Falster Jakobsen, L., Kragh, K.J., Lindschow, J. \& Strudsholm, E. (red.). København: Dansk Sprognævn, 121-140.

Terrell, T.D. \& Hooper, J. (1974): A semantically based analysis of mood in Spanish. Hispania 57 (3), 484-94. 